\title{
Post-strengthening of reinforced concrete beams with prestressed CFRP strips. Part 1: Analysis under static loading.
}

\section{Reforço de vigas de concreto armado com laminados de PRFC protendidos. Parte 1: Análise sob ação de carregamento estático}
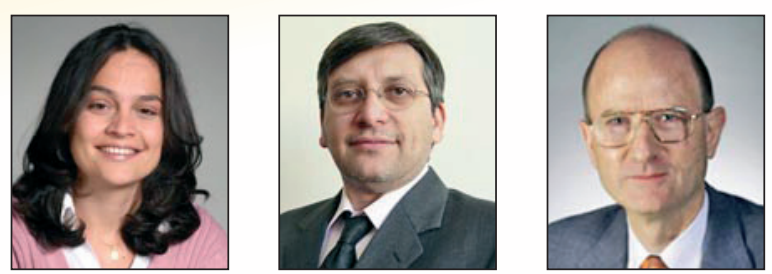

M. R. GARCEZ a mrgarcez@hotmail.com

G. L. C. P. SILVA FILHO b Icarlos66@gmail.com

URS MEIER mrgarcez@hotmail.com

\begin{abstract}
Different FPR post-strengthening techniques have been developed and applied in existing structures aiming to increase their load capacity. Most of the FRP systems used nowadays consist of carbon fibers embedded in epoxy matrices (CFRP). Regardless of the advantages and the good results shown by the CFRP post-strengthen technique, experimental studies show that, in most cases, the failure of post-strengthened structures is premature. Aiming to better use the tensile strength of the carbon fiber strips used as post-strengthening material, the application of prestressed CFRP strips started to be investigated. The main purpose of this paper is to analyze the effects of the composite prestressing in the performance of the CFRP post strengthening technique. The experimental program was based on flexural tests on post-strengthened reinforced concrete beams subjected to static - part 1 and cyclic - part 2 loading. Experimental results allowed the analysis of the quality and shortcomings of post-strengthen system studied, which resulted in valuable considerations about the analyzed post-strengthened beams.
\end{abstract}

Keywords: prestressing, FRP, strips, carbon fiber, concrete structures, fatigue.

\section{Resumo}

Diferentes técnicas de reforço que utilizam sistemas PRF formados com fibras de carbono envolvidas em matriz epoxídica (PRFC) têm sido aplicadas em todo o mundo em estruturas que necessitam aumentar recuperar sua capacidade resistente. Apesar dos bons resultados obtidos e das vantagens associadas a estas técnicas, estudos experimentais mostram que a ruptura das estruturas reforçadas freqüentemente acontece de forma prematura, sem o esgotamento da capacidade resistente do PRFC. Recentemente, a utilização de PRFC protendidos começou a ser investigada, visando a um melhor aproveitamento da resistência à tração dos laminados de fibra de carbono. Dentro deste propósito, este artigo busca analisar a eficiência da técnica de protensão de compósitos laminados, através da realização de ensaios à flexão com carregamento estático - parte 1 e cíclico - parte 2. Os resultados obtidos possibilitaram a análise das qualidades e fraquezas do sistema de reforço estudado, permitindo a obtenção de considerações relevantes sobre as estruturas reforçadas estudadas.

Palavras-chave: protensão, PRF, laminados, fibra de carbono, estruturas de concreto, fadiga.

Dra., Federal University of Pelotas (UFPel), mrgarcez@hotmail.com, Engineering Center, Pelotas - RS, 96010-900, Brazil.

PhD., Laboratory of Testing and Structural Modeling (LEME), Departament of Civil Engineering, Federal University of Rio Grande do Sul, Icarlos66@gmail.com, Osvaldo Aranha 99, Centro, Porto Alegre - RS, 90035-190, Brazil.

Doctor Honoris Causa, EMPA, Dübendorf, Suiça. 


\section{Introduction}

Reinforced concrete structures are, frequently, submitted to interventions aiming to restore or increase their original load capacity. According to Garden \& Hollaway [1], the choice between upgrading and rebuilding is based on factors specific to each individual case, but certain issues are considered in every case. These are the length of time during which the structure will be out of service or providing a reduced service, relative costs upgrading and rebuilding in terms of labor, materials and plant, and disruption of other facilities.

Several post-strengthening techniques were developed in the last decades. Most of them are based on the addiction of a structural element to the external face of the element to be post-strengthened. According to Täljsten [2], the method of post-strengthening existing structures with steel plates bonded to the structure with epoxy adhesive was originated in France, in the nineteen sixties, when L'Hermite (1967) and Bresson (1971) carried out tests on poststrengthened concrete beams. There is also reported use of this post-strengthening method in South Africa from 1964 by Dussek (1974). In both cases the post-strengthening was successful and the load bearing capacity was increased. These first investigations in France and South Africa inspired future research in Switzerland (1974), Germany (1980), United Kingdom (1980), Japan (1981) and Belgium (1982). The idea of post-strengthen existing reinforced concrete structures with bonded steel was improved due to the development of synthetic adhesives, based on epoxy resins, suitable to ensure good adhesion and chemical resistance to aggressive agents.

In the last decades, non-corrosive, low-weight and high-resistant materials started to be developed and applied on the construction of new buildings, aiming to produce durable structures. These materials, called Fiber Reinforced Polymers (FRP), started to be investigated in the middle 80's at EMPA (Swiss Federal Laboratories for Materials Testing and Research), in Switzerland. At that time, the carbon fiber was elected as the most suitable for post-strengthening applications due to its low-weight, high tensile strength, high modulus of elasticity and resistance to corrosion. Since then, many structures were post-strengthened with FRP in Japan, Europe, Canada and United States and nowadays the use of FRP is growing worldwide.

Most of FRP post-strengthening systems used nowadays consist of carbon fibers embedded in epoxy matrices and provide high modulus of elasticity and tensile strength. The main impediment to the massive use of CFRP (Carbon Fiber Reinforced Polymers) regards to the high cost of the carbon fiber that, in Brazil, may reach US $\$ 50,00 / \mathrm{m}^{2}$, depending on the post-strengthening system. Meier, in 2001 [3], pointed out that the functionality and the mechanical properties of CFRP should be better explored, due to its relatively high cost. Indeed, the use of only $10 \%-15 \%$ of the tensile strength of the CFRP, as it happens in some bonded poststrengthening systems, is not economically viable.

Aiming to contribute to the evolution of the CFRP post-strengthening technique, this paper intends to analyze the efficiency of prestressed CFRP used on the post-strengthening of reinforced concrete beams, by means of static - part 1 and cyclic - part 2 loading tests, as an alternative to better use the tensile strength of these materials.

\section{Application of prestressed FRP strips on the post-strengthening of reinforced concrete beams}

The aim in prestressing concrete beams may be, according to Garden and Mays [4], either to increase the serviceability capacity of the structural system of which the beams form a part or to extend its ultimate limit state.

According to El-Hacha [5], FRP are well suited to prestressing applications because of their high strength-to-weight ratio that provides high prestressing forces, without increases on the selfweight of the post-strengthened structure. The prestressing technique may improve the serviceability of a structural element and delay the onset of cracking. When prestressed FRP are used, just a small part of the ultimate strain capacity of the material is used to prestress the FRP, the remaining strain capacity is available to support external loads and also to ensure safety against failure modes associated to peeling-off at the border of flexural cracks and at the ends of the post-strengthening.

Several FRP prestressing systems are currently available consisting of rods, strands, tendons or cables of FRP. However, in some cases, it may be advantageous to bond FRP sheets or strips onto the structural element surface in a prestressed state. According to the Bulletin 14 of fib [6], prestressing the FRP prior to bonding has the following advantages:

- Provides stiffer behavior as at early stages most of the concrete is in compression and therefore contributing to the moment of resistance. The neutral axis remains at a lower level in the prestressed case if compared to the unstressed one, resulting in greater structural efficiency.

- Crack formation in the shear span is delayed and the cracks, when they appear, are more finely distributed and narrower. Thus, serviceability and durability are improved, due to reduced cracking.

- The same level of strengthening is achieved with smaller areas of stressed FRP, compared to unstressed ones.

- Prestressing significantly increases the applied load at which the internal steel reinforcement begins to yield if compared to an unstressed structural member.

On the other hand, prestressing FRP systems are more expensive than the non-prestressed ones, due to the greater number of operations and the equipment that is required to prestress the FRP.

\subsection{Losses of prestressing force}

Prestressed FRP bonded to concrete structures are sujected to prestress losses, as it happens in any prestressing system. Such prestress losses may be instantaneous, due to immediate elastic deformation of concrete, or time dependent, due to creep and shrinkage of concrete and relaxation of the FRP.

Immediate elastic deformation of the concrete may reach $2 \%$ to $3 \%$, according to the Bulletin 14 of fib [6], and happens when the prestress force is transferred into the concrete beam. If prestress is applied by reacting against the structural member there will be no loss. It happens because if the prestressing device if fixed on the structural element that will be post-strengthened, a compensation occurs: as the PRF is being stressed, the concrete is being compressed. However, FRP elements that have already been pre- 


\section{Figure 1 - (a) Premature failure of a prestressed CFRP strip without anchorage; (b) Action of an anchorage system (Triantafillou et al. (8))}

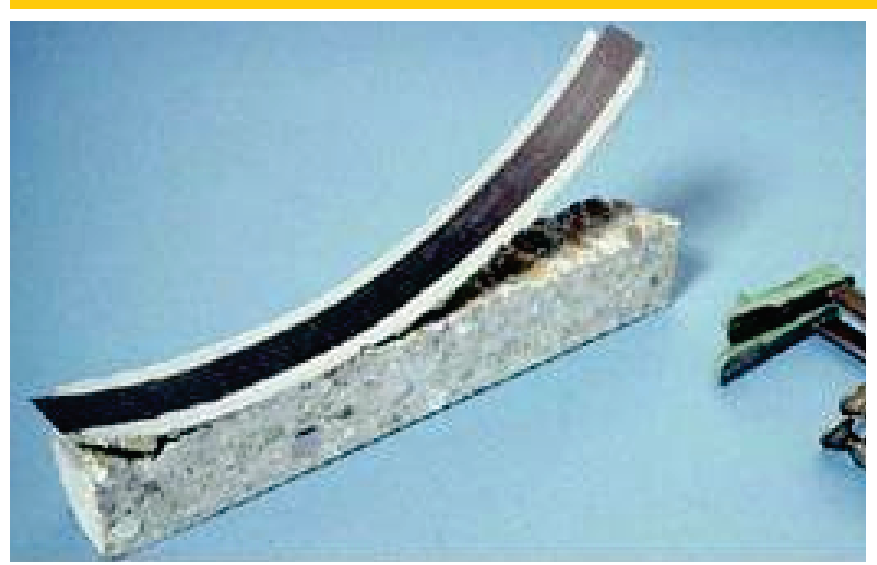

(A)

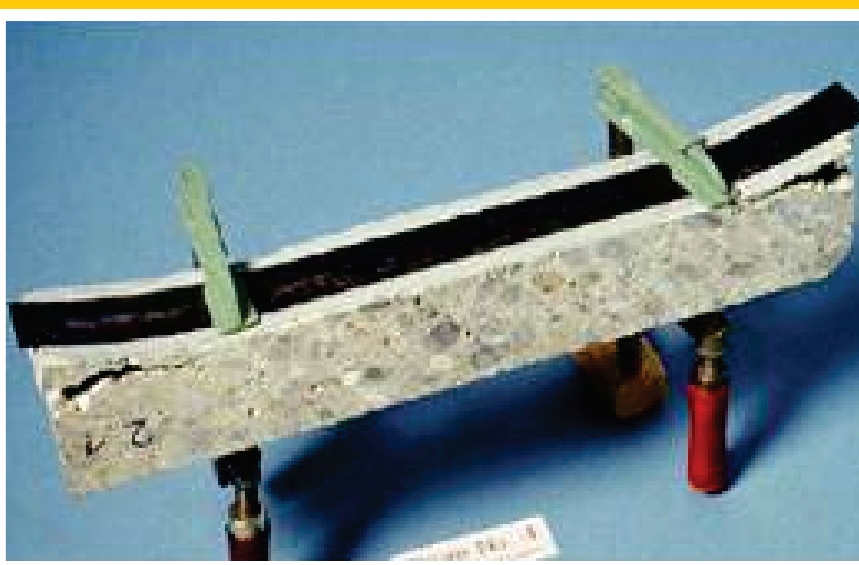

B stressed will experience a loss of prestress due to the shortening of the beam upon the prestressing of subsequent FRP elements. In such cases it is necessary to determine the average loss of prestress per FRP element.

Time dependent losses, due to creep and shrinkage of concrete, according to the Bulletin 14 do fib [6], reach about 10 to $20 \%$ and are similar to the ones of conventional prestressing.

Prestressing losses due to relaxation of FRP depends, according to $\mathrm{ACl} 440.4 \mathrm{R}-04$ [7], on the characteristics of the FRP composite. The document also informs that losses due to relaxation of fibers may be neglected when CFRP are used, since the relaxation of carbon fibers is very low. Losses of 0,6 to $1,2 \%$ must be considered due to the relaxation of the polymer and losses of 1 to $2 \%$ must be considered due to the straightening of fibers.

Results of a research program developed by Triantafillou et al. [8] indicate that, when prefabricated CFRP are used, prestress losses of $10 \%$ must be considered, due to the instantaneous and time dependent losses at the concrete and adhesive and also due to the relaxation of the CFRP.

Garden and Mays [4] consider that prestressed FRP also suffer prestress losses due to the shear transferred through the adhesive and into the concrete by the FRP tension. This shear action is sufficient to fracture the concrete even at low prestress levels so it is necessary to install anchorages at the ends of the FRP element to resist this action.

\subsection{Maximun prestressing force}

Figure [01] (a), by Triantafillou et al. [8], shows the premature failure of a concrete beam post-strengthened with a CFRP strip, without any anchorage system, immediately after the complete release of the prestressing force. Horizontal shear cracks propagated from both ends of the CFRP strip through the concrete layer and stopped at a certain length. Figure [01] (b) shows that this failure mode may be prevented if anchorage systems are used at the ends of the strips. The authors suggest that the maximum pre- stressing force that avoids the need of anchorage systems provide very low prestressing levels, $15 \%$ to $20 \%$, depending on the cross section of the CFRP strip.

Thus, the addition of anchors at the end of the prestressed FRP sheets or strips reduces the shear deformation that occurs within the resin or adhesive layer upon releasing the prestress force and reducing the shear stresses transferred to the base of the concrete section. Thereby, anchorage systems minimize the possibility of premature failures (El-Hacha [5]).

According to El-Hacha et al. [9], prestressing levels of at least $25 \%$ of the FRP tensile strength may be necessary to achieve a significant improvement in terms of the structural stiffnes and load carrying capacity.

Meier [10] suggests that a prestress level as high as $50 \%$ of the CFRP strength might be necessary to increase the ultimate strength by delaying the premature failure. Experimental results presented by Deuring [11] showed that increasing the level of prestress in the CFRP from $50 \%$ to $75 \%$ reduced the strength of the beam because the highly prestressed laminates had little strain capacity remaining and the CFRP presented premature failure. It is important to have in mind that, when post-strengthening is prestressed the modulus of elasticity of the FRP is of great significance, once the FRP element needs to be stiffer to hold up a significant loading that, before the post-strengtnening, was made only by the steel reinforcement (El-Hacha, [5]).

\subsection{Prestressing method developed by Stoecklin and Meier [12]}

Stoecklin e Meier [12] developped, at EMPA (Swiss Federal Laboratories for Material Testing and Research) a method to apply prestressed FRP strips to concrete structures. In this method, the FRP strip is first prestressed then bonded at the beam that will receive the post-strengthening. Since it is very complicated to grab and prestress the FRP strip, due to its anisotropic behavior, a prestressing device was designed, as one can see in Figure [02]. The 
Figure 2 - Prestressing device developed by Stoecklin \& Meier (12): (a) Placement of the prestressing device under the beam; (b) Two ways of prestressing a CFRP strip

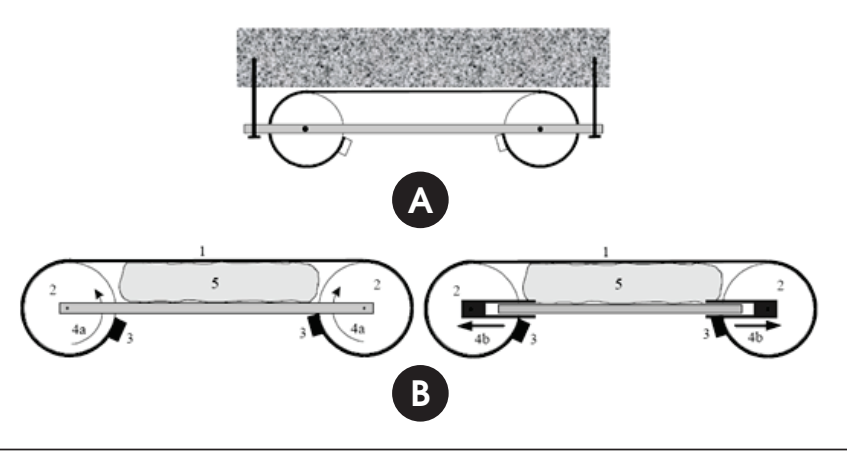

prestressing device consists of two wheels which are connected to a beam of the required length, as shown Figure [02] (a).

The FRP strip (1) is wrapped around the wheels (2) and clamped at its ends (3) as shown in Figure [2] (b). The strip can be prestressed by rotating one or both wheels (4a) or displace the wheels (4b). As one can see in Figura [02] (a), the prestressing device with the prestressed FRP strip is temporarily mounted to the structure and can be pressed against the structure with a constant pressure by means of an air-cushion (5) between the FRP strip and the beam. (Stoecklin e Meier [12]).

In a new version of the prestressing device developed by Stoecklin and Meier [12], two separate prestressing units at each end of the strip are directly mounted to the structure, what means that the FRP strip is prestressed against the structure, as shown in Figure [3].

To overcome anchorage problems at the ends of the FRP strips, the prestressing force can be reduced gradually from the mid-span to both ends of the FRP strips.

As described by Meier et al. [13], gradual anchoring is achieved by first bonding a fully pretensioned section in the middle of the FRP strip at mid-span. A system of electric heating may be used to speed up curing of the adhesive in the bonded section within the pot life of the adhesive. After curing the central part of the FRP strip at mid-span, the prestressing force is slightly reduced and another section is bonded at each side of the strip also using the electric heating system to speed up curing the adhesive.

Figure 3 - New version of the prestressing device develloped by Stoecklin \& Meier (12)

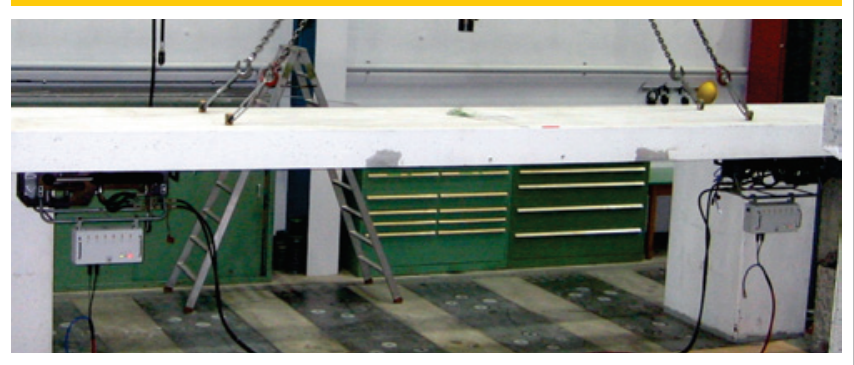

Figure 4 - Gradual anchorage of prestressed CFRP strips (Stoecklin \& Meier (12))

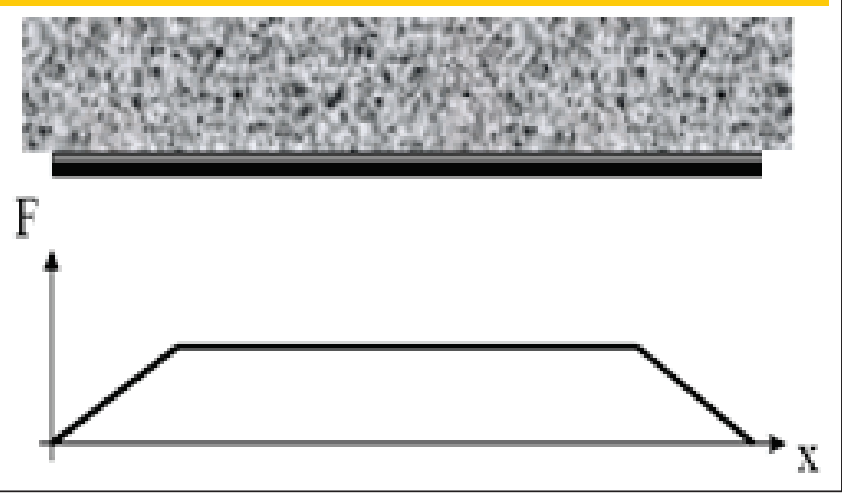

This process is repeated in several stages until the entire length of the strip is bonded and the prestressed level at the ends of the strips has been reduced to a low level, as one can see in Figure [4]. In this way, anchorages are not required at the end of the prestressed strip. In the prestressing method developed by Stoecklin and Meier [12] the strip is prestressed before the application at the beam. In such case, prestressing is applied by reacting against the structural member, since the prestressing device is mounted to the structure. When the first FRP strip is prestressed, using the device developed by Stoecklin and Meier [12], imediate losses of prestress due to elastic deformation of the concrete, that happen when the prestress force is released, can be neglected, since prestressing is applied by reacting against the structural member. However, strips that have already been prestressed will experience a loss of prestress due to the shortening of the beam upon the prestressing of subsequent FRP strips.

\subsection{Failure Modes of reinforced concrete beams post-strengthened with prestressed FRP, submitted to static loading}

According to Hollaway [14], the anisotropic behavior of the composite materials leads to a complex rupture mechanism that may be characterized by extensive damages on the composite material when submitted to static and cyclic loading. The level of damage, however, depends on the properties of the composite material and on the applied loading.

Failure modes of reinforced concrete structures post-strengthened with FRP include crushing of concrete, yielding of steel reinforcement or tensile failure at the FRP.

Teng et al. [15] report that failure modes of reinforced concrete beams post-strengthened with FRP can be broadly classified into two types: those associated with high interfacial stresses near the ends of the bonded FRP and those induced by a flexural or flexural-shear crack away from the ends, which is also referred to as intermediate crack-induced debonding. Thus premature failures, in general, are associated to:

- High interfacial stresses near to the ends of the bonded FRP, also called peeling-off.

- Flexural or flexural-shear crack away from the ends, as shown in Figure [5]. 


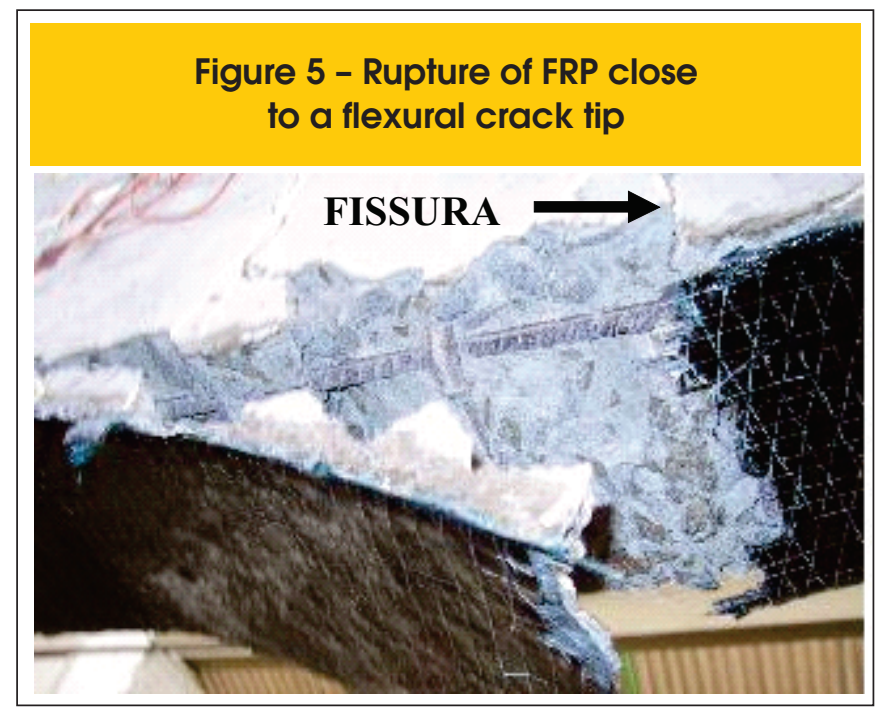

Concrete structures post-strengthened with prestressed FRP also show premature failures as described by Teng et al. [15]. However, in prestressed systems, the high strength of the FRP used to post-strengthen structures is much better used, and, depending on the configuration of the post.-strengthening, tensile failure of the FRP may be achieved. Garden and Hollaway [1] presented, in 1998, a specific study regarding the failure modes of reinforced concrete beams poststrengthened with prestressed FRP, with prestressing levels ranging from $25 \%$ to $50 \%$ of the FRP strength. Results showed that a high prestress level was required to enable the ultimate capacity of strip to be reached, before shear displacement reached its critical value.

According to Garden and Mays [4], the level of prestress that can be applied will be limited by the tensile strength of the FRP. Tensile failure of the FRP should not precede either yielding of steel reinforcement or crushing of concrete, to ensure adequate ductility. Results of the experimental program

\section{Table 1 - Description of Experimental Program}

$\begin{array}{ccc}\text { Beam } & \text { Post-strengthening } & \text { Prestressing level } \\ \text { VT } & - & - \\ \text { VFC_NP_01 } & \begin{array}{c}\text { Two CFRP } \\ \text { non-prestressed } \\ \text { strips } \\ \text { Two CFRP } \\ \text { VFC_PE_01 } \\ \text { prestressed } \\ \text { strips }\end{array} & - \\ & & \text { 35\% of } \varepsilon_{\mathrm{fu}} \\ \end{array}$

showed that the level of prestress may also have to be limited by the strength of the anchorage devices, by the horizontal shear strength of the adhesive/FRP interface and by the bottom layers of concrete.

\section{Experimental program}

\subsection{Description of specimens}

Table [1] describes the first stage of the experimental program, which aims to investigate the behavior of reinforced concrete beams post-strengthened with prestressed CFRP strips under static loading.

\subsection{Reinforced concrete beams}

The reinforced concrete beams were rectangular, $6500 \mathrm{~mm}$ long, $1000 \mathrm{~mm}$ wide, and $220 \mathrm{~mm}$ deep. All beams were reinforced with seven bottom $15 \mathrm{~mm}$ steel bars $(r=0,0041)$. The shear reinforcement consisted of $8 \mathrm{~mm}$ steel stirrups spaced each $90 \mathrm{~mm}$ $\left(11,17 \mathrm{~cm}^{2} / \mathrm{m}\right)$. Geometry and reinforcement details for the beam are shown in Figure [6].

Figure 6 - Geometry and reinforcement details of tested beams
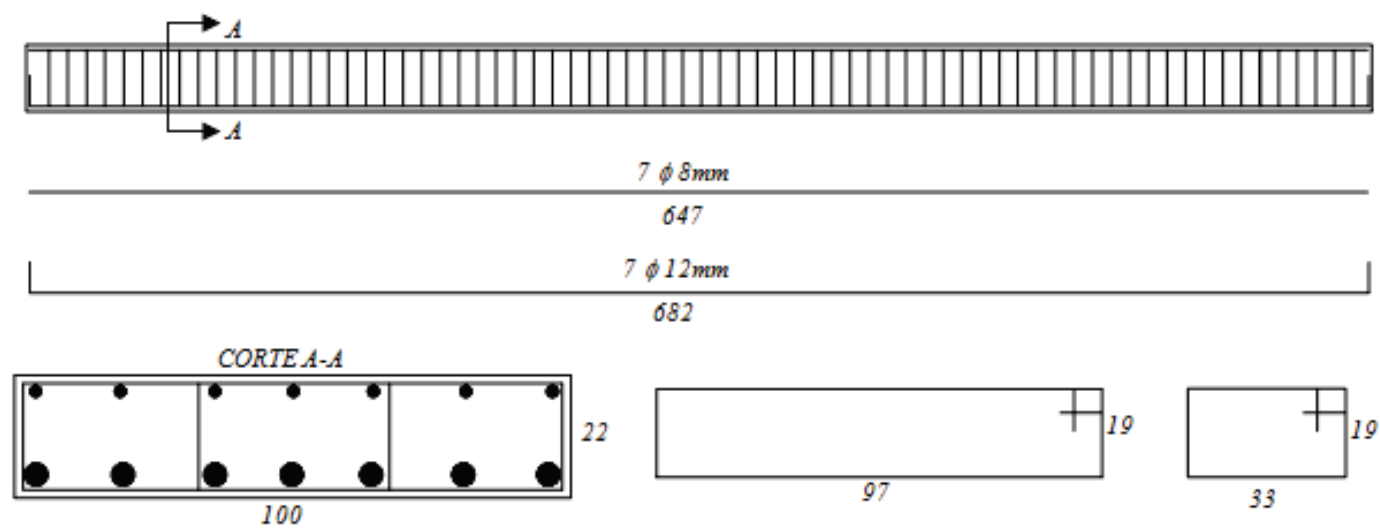
Table 2 - Post-strengthening system characteristics

\begin{tabular}{|cc|}
\hline Thickness (mm) & $\begin{array}{c}\text { Carbodur S } 512 \\
\text { Strip }\end{array}$ \\
\hline Width (mm) & 1,2 \\
Tensile Strength (MPa) & 50 \\
Ultimate Strain (\%o) & 2.800 \\
Young's Modulus (MPa) & 17 \\
\hline
\end{tabular}

Pot life at $25^{\circ} \mathrm{C}(\mathrm{min})$

Pot life at $35^{\circ} \mathrm{C}(\mathrm{min})$

Pot life at $55^{\circ} \mathrm{C}(\mathrm{min})$

$$
\operatorname{Tg}\left({ }^{\circ} \mathrm{C}\right)
$$

Young's Modulus (MPa)
40

$-$

62

12.800
60

30

107

10.000
The aggregates used to produce the concrete were the ones available in the Switzerland region and the cement was the Portland CEM I 42,5 (95\% of clinquer, and $5 \%$ of other components), equivalent to the Brazilian CPI. The average compressive stress (cube strength) of the concrete, after 28 days, was $44 \mathrm{MPa}$.

The $8 \mathrm{~mm}$ steel bars had average yield stress, yield strain, ultimate stress and modulus of elasticity of $554 \mathrm{MPa}, 2,51 \%$, $662 \mathrm{MPa}$ e $220 \mathrm{Gpa}$, as indicated by tensile tests. The $12 \mathrm{~mm}$ steel bars had average values of: $436 \mathrm{MPa}, 1,98 \%$, $688 \mathrm{MPa}$ e $215 \mathrm{GPa}$.

\subsection{Post-strengthening system}

Sika ${ }$ Carbodur (Carbodur S 512 and Sikadur $®-30$ ) was the CFRP system used to post-strengthen the beams. However, Sikadur $(-$ 30LP adhesive was used to bond the prestressed strips to the con- crete, due to its extended pot life. Table [2] shows the characteristics of the strips and adhesive, provided by manufacturer.

\subsection{Post-strengthening procedure}

The application of Sika ${ }^{\circledR}$ Carbodur system demands a surface preparation for the concrete and the strip. The concrete surface must be clean and free from grasses and oil, dry and have no loose particles. Considering the application of prestressed strips, after concrete and strip surface preparation, the strip is clamped, prestressed and covered with Sikadur $(-30$ LP adhesive. Then, thermocouples are settled at the strip aiming to control the temperature applied to accelerate the cure of the adhesive. Figure [7] shows the application of epoxy adhesive on the strip and the procedure to clamp the strip on the prestressing device.

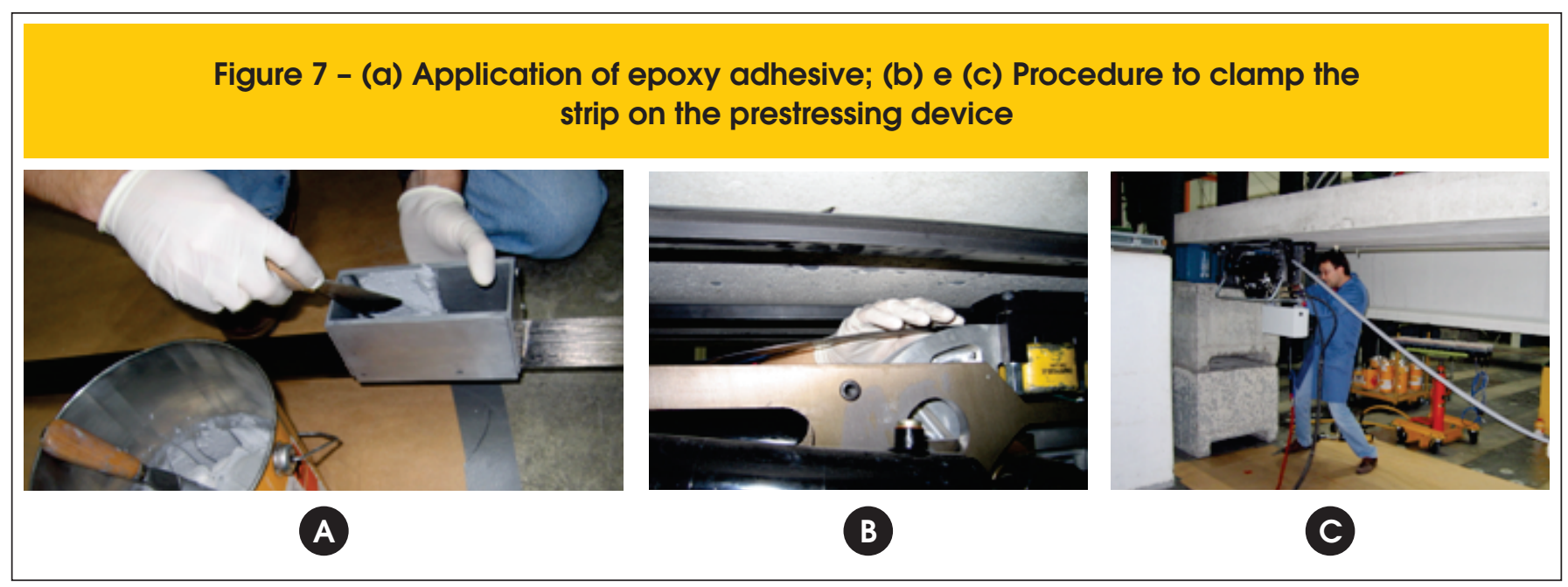




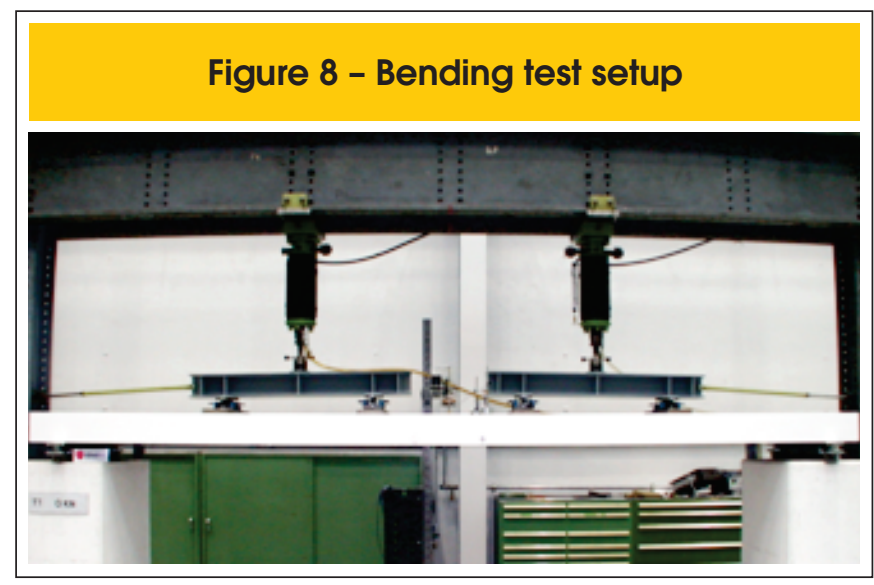

A gradual anchorage system was applied: after the cure of the adhesive at the middle part of the beam, the prestressing force was marginally reduced and the following areas were bonded. The force was reduced further and the adjacent areas were bonded. This procedure was repeated until there was no remaining prestressing force at the ends of the strip. With the gradual reduction, the level of prestress applied at the ends of the strip is very low or close to zero, eliminating the need of additional anchorage systems.

The maximum prestressing force applied to prestress the strip was $60 \mathrm{kN}$, at mid-span. Then, prestressing force was reduced, gradually, to $48 \mathrm{kN}, 36 \mathrm{kN}, 24 \mathrm{kN}, 12 \mathrm{kN}$ and, finally, zero, at the ends.

\subsection{Test Procedure}

Loading was applied according to a six point bending test scheme: simple supported beam and four vertical loads, spaced by $12000 \mathrm{~mm}$, symmetrically applied along the $6000 \mathrm{~mm}$ span.

Load was applied by two $100 \mathrm{kN}$ hydraulic jacks. During the tests, values of deflection at mid-span and specific strain at steel, concrete and FRP were continuously recorded by a computer controlled data acquisition system. Bending test setup is shown in Figure [8].

\section{Results and discussion}

\subsection{Loads and failure modes}

Table [3] shows that the flexural capacity of beam VFC_NP_01,

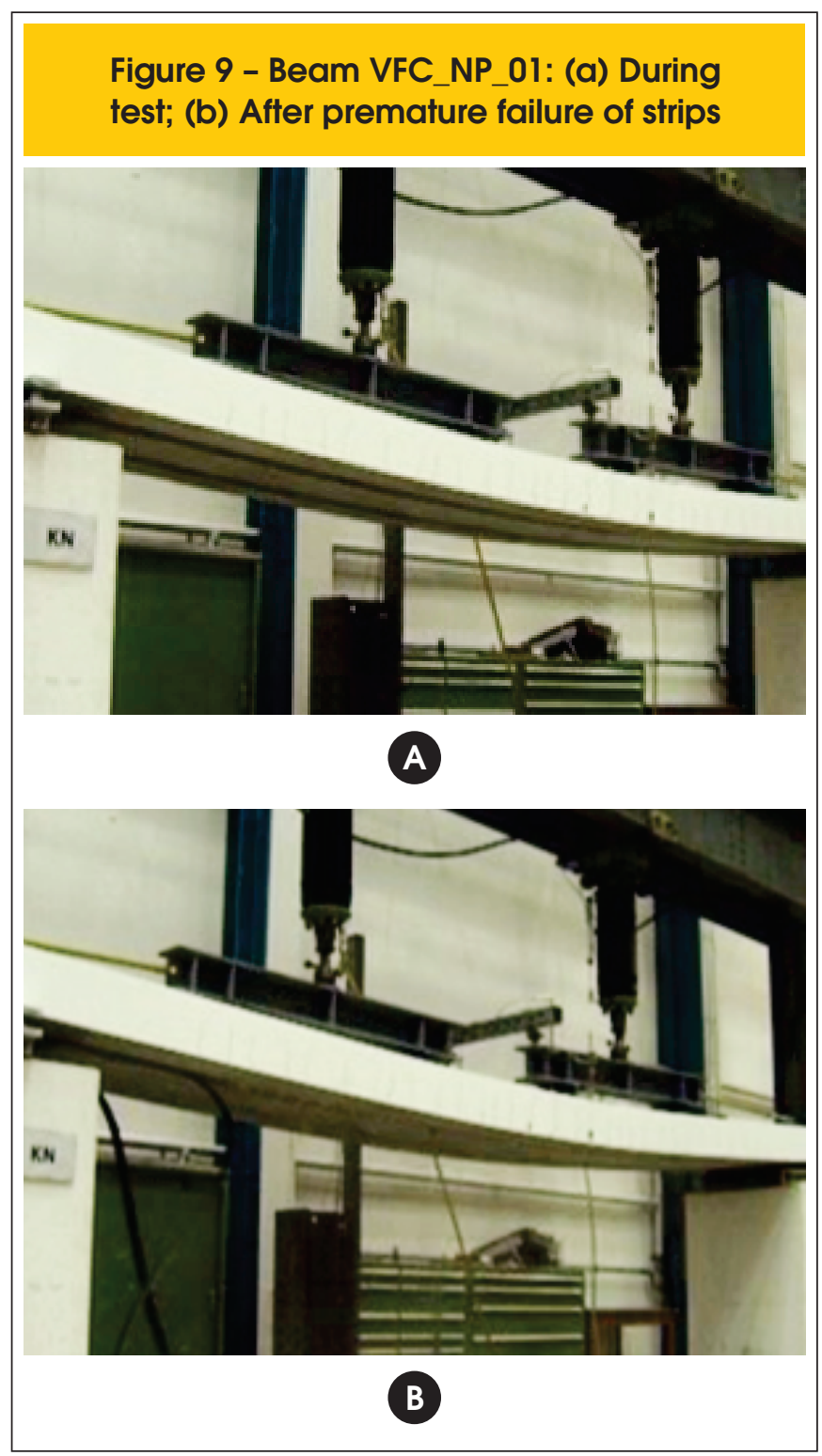

post-strengthened with two non-prestressed CFRP strips, increased $27 \%$ when compared to the control beam. On the other hand, post-strengthening of beam VFC_PE_01, two prestressed

\section{Table 3 - Ultimate Loads and failure modes of post-strengthened beams tested under static loading}

\begin{tabular}{|cccc|}
\hline Beam & Post-strengthening & Ultimate load & $\begin{array}{c}\text { Failure Mode } \\
\text { VT }\end{array}$ \\
VFC_NP_01 & - & $100,14 \mathrm{kN}$ & $\begin{array}{r}\text { Yielding of steel followed by } \\
\text { concrete crushing }\end{array}$ \\
VFC_PE_01 & $\begin{array}{c}\text { Two } 1,2 \mathrm{~mm} \times 50 \mathrm{~mm} \\
\text { non-prestressed strips } \\
\text { Two } 1,2 \mathrm{~mm} \times 50 \mathrm{~mm}\end{array}$ & $127,25 \mathrm{kN}$ & Premature failure (peeling-off) \\
& prestressed strips & $162,41 \mathrm{kN}$ & Premature failure (peeling-off) \\
\hline
\end{tabular}


CFRP strips, increased $62,41 \%$ the load bearing capacity of the beam.

Results of beams VFC_NP_01 and VFC_PE_01 can be explained by the principles of prestressing. When the prestressing force applied on the CFRP strips is released, compressive stresses are induced on the concrete. Such compressive stresses delay the concrete cracking and the yielding of the steel reinforcement. Thus, the load bearing capacity of the post-strengthened element is increased. Premature failures (peeling-off) of beams VFC_NP_01 and VFC_ PE_01 occurred due to the high interfacial stresses near to the ends of strips.

Peeling-off failures are catastrophic and happen without any previous advice. Figure [9] (b) shows two CFRP strips of beam VFC_ NP_01 after peeling-off. Both strips are completely detached from the beam; however, strips do not present any damage, once the failure occurred at the concrete/adhesive interface.

\subsection{Displacements at mid-span}

Figure [10] shows that all post-strengthened beams present similar behavior regarding stiffness until concrete cracking. Results indicate that in such cases the action of the post-strengthening begins just when the structural element is already cracked.

Beam VFC_NP_01 post-strengthened with non-prestressed strips and the control beam, showed no significant difference regarding stiffness. However, beam VFC_PE_01 showed a stiffer behavior, when compared to beans control and VFC_NP_01, due to the increase of the cracking load and the later yielding of the reinforcement steel. Control beam and beam VFC_NP_01, post-strengthened with non-prestressed CFRP strips present similar values of loading and displacement at mid-span at concrete cracking, due to the fact that the post-strengthening begins to act just after concrete cracking. Cracking load of beam VFC_PE_01 was 57\% higher than the ones of control beam and beamVFC_NP_01. Differences at the first stage of the loading versus displacement response at mid-span happen because prestressing leads to the development of compressive stresses at the bottom face of the beam. When non-prestressed strips are applied, the bottom face of the beam is already tensioned at the beginning of the loading process. Thus, when post-strengthening is prestressed, the loading needed to crack the concrete is significantly higher.

Differences regarding yielding of the reinforcement steel were significant. Increasing of $22 \%$ for beam VFC_NP_01 and $45 \%$ for beam VFC_PE_01, related to control beam, was observed.

\subsection{Anchorage system}

The gradual anchorage system worked properly and allowed the use of $83 \%$ of the tensile strength of the strips. Advantages of the gradual anchorage include the fact that the same device is used to prestress the strip and to gradually reduce the prestress load from the mid-span to the ends of the strip. The result is a prestressed CFRP strip without any external anchorage systems.

\section{Conclusions}

Results obtained with the development of the research program allowed the investigation of changes on the behavior of poststrengthened elements due to prestressing.

\section{Figure 10 - Load vs Displacement response of the beams tested under static loading}

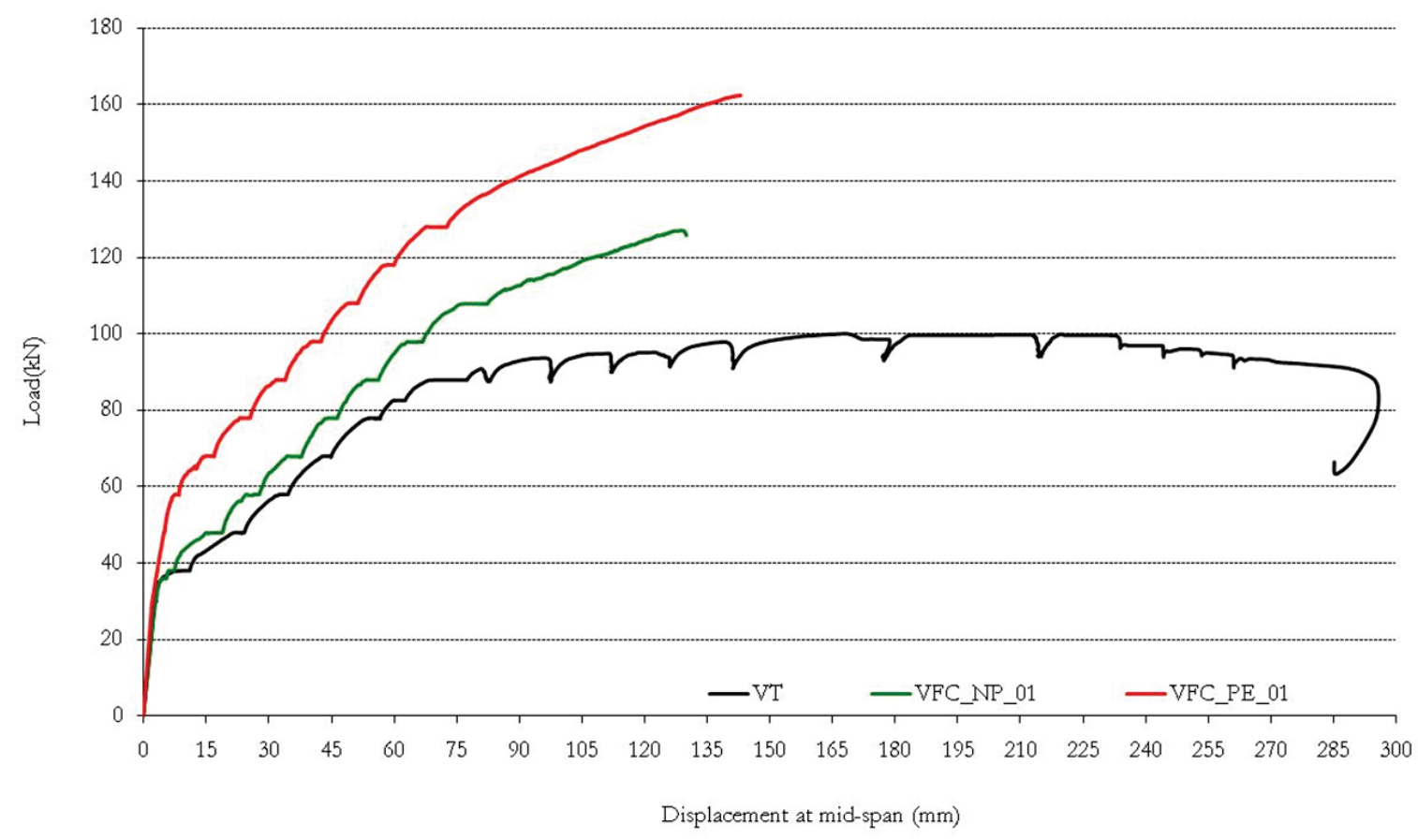


The increasing on the load bearing capacity of the beam poststrengthened with prestressed strips, higher than the one of the beam post-strengthened with non-prestressed strips, highlights the efficiency of the prestressing technique.

All post-strengthened beams showed vertical displacements at mid-span lower to the ones of the control beam. However, the stiffer behavior showed by all post-strengthened beams was evidenced only after concrete cracking. Due to the increasing of the concrete cracking load and the later yielding of the reinforcement steel, the beam post-strengthened with prestressed CFRP strips showed a stiffer behavior when compared to the one post-strengthened with non-prestressed CFRP strips.

Gradual anchorage worked properly, dismissed the use of any external anchorage system and allowed the use of $83 \%$ of the tensile strength of the strip.

In this paper, the efficiency of prestressing was verified by means of bending tests under static loading. However it is also necessary to verify the behavior of the prestressed post-strengthening under cyclic loading, aiming to identify possible changes on the behavior of prestressed strips and on the gradual anchorage. This topic will be addressed at the second part of this paper.

\section{Acknowledgements}

Authors would like to acknowledge CNPq (Portuguese acronym of the Brazilian Ministry of Science's National Research Council) and CAPES (Portuguese acronym of the Brazilian Ministry of Education's Higher Education Human Resources Development Agency) for providing the financial support needed to develop this project. Authors would also like to express their appreciation for the technical support given by the research team at EMPA (Swiss Federal Laboratories for Materials Testing and Research), in Switzerland.

\section{References}

[01] GARDEN, H. N. \& HOLLAWAY, L. C. An experimental study of the failure modes of reinforced concrete beams strengthened with prestressed carbon composite plates. Composites Part B, volume 29B, 1998. p. 411-424.

[02] TÄLJSTEN, B. Strengthening of existing concrete structures with epoxy bonded plates of steel or fibre reinforced plastics. Lulea: Lulea University, 1994. 190p. Tese (Doutorado em Engenharia Civil) - Lulea University, 1994.

[03] MEIER, U. Polyfunctional use of advanced composite materials with concrete. In: THIRD INTERNATIONAL CONFERENCE ON CONCRETE UNDER SEVERE CONDITIONS, 2001, Vancouver. Anais... Vancouver: THIRD INTERNATIONAL CONFERENCE ON CONCRETE UNDER SEVERE CONDITIONS, 2001. [CD-Rom]

[04] GARDEN, H. N., MAYS, G. C. Strengthening of Reinforced Concrete Structures Using Externally bonded FRP Composites in Structural and Civil Structures. Cambridge: CRC Press, 1999. 327p.

[05] EL-HACHA, R. M. A. Prestressed CFRP for strengthening concrete beams at room and low temperatures.
Kingston: Queen's University, 2000. 511p. Tese (Doutorado em Engenharia Civil) - Queen's University, 2000.

[06] FÉDÉRATION INTERNATIONALE DU BETÓN. Externally bonded FRP reinforcement for $R C$ structures - Bulletin 14. Lausane: FIB, 2001. Technical Report - Fédération Internationale du Betón, 2001.

[07] AMERICAN CONCRETE INSTITUTE. Prestressing Concrete Structures with FRP Tendons: ACI 440.4R-04. Farmington Hills, 2004. 35p.

[08] TRIANTAFILLOU, T. C., DESKOVIC, N., DEURING, $M$. Strengthening od concrete structures with prestressed fiber reinforced plastic sheets. $\mathrm{ACl}$ structural Journal, volume 89, número 3, maio/junho, 1992. p. 235-244.

[09] EL-HACHA, R. , WIGHT, G., GREEN, M. F. Prestressed carbon fiber reinforced polymer sheets for strengthening concrete beams at room and low temperatures. Journal of Composites for Construction, janeiro/fevereiro, 2004. p. 3-13.

[10] MEIER, U. Design and rehabilitation of concrete structures using advanced composite materials. In: PRE CONGRESSO LATINO-AMERICANO DE PATOLOGIA DA CONSTRUÇÃO, 2005, Porto Alegre. Anais... Porto Alegre: PRECONPAT, 2005. [CD-Rom]

[11] DEURING, M. Verstärken von Stahlbeton mit gestpannten Faserverbund-Werkstoffen. Dübendorf: EMPA, 1993. 276p. Report 224 - Swiss Federal Laboratories for Materials Testing and Research, 1993.

[12] STÖCKLIN, I., MEIER, U. Strengthening of concrete structures with prestressed and gradually anchored CFRP. In: SIXTH INTERNATIONAL SYMPOSIUM ON FRP REINFORCEMENT FOR CONCRETE STRUCTURES, 2003, Singapore. Anais... FRPRCS-6. 2003. [CD-Rom]

[13] MEIER, U., STÖCKLIN, I., TERRASI, G. P. Making better use of the strength of advanced materials in structural engineering. In: FRP COMPOSITES IN CIVIL ENGINEERING, 2001, Hong Kong. Anais... Hong Kong: FRP COMPOSITES IN CIVIL ENGINEERING, 2001. [CD-Rom]

[14] HOLLAWAY, L. Polymer Composites for Civil and Structural Engineering. Hong Kong: Blackie Academic and Professional, 1993. 253p.

[15] TENG, J. G., SMITH, S. T., YAO, J. e CHEN, J. F. Intermediate crack-induced in RC beams and slabs. Construction and Building Materials, volume 17, 2003, p $447-462$. 